University of Rhode Island

DigitalCommons@URI

2016

\title{
A Method to Estimate Climate-Critical Construction Materials Applied to Seaport Protection
}

\author{
Austin Becker \\ University of Rhode Island, abecker@uri.edu \\ Nathan Chase \\ Martin Fischer \\ Ben Schwegler \\ Keith Mosher
}

Follow this and additional works at: https://digitalcommons.uri.edu/maf_facpubs
The University of Rhode Island Faculty have made this article openly available.
Please let us know how Open Access to this research benefits you.

This is a pre-publication author manuscript of the final, published article.

Terms of Use

This article is made available under the terms and conditions applicable towards Open Access

Policy Articles, as set forth in our Terms of Use.

\section{Citation/Publisher Attribution}

Becker, A., Chase, N.T.L., Fischer, M., Schwegler, B., Mosher, K. (2016) A method to estimate climatecritical construction materials applied to seaport protection. Global Environmental Change, 40, 125-136, DOI 10.1016/j.gloenvcha.2016.07.008, ISSN 09593780.

Available at: http://dx.doi.org/10.1016/j.gloenvcha.2016.07.008

This Article is brought to you for free and open access by the Marine Affairs at DigitalCommons@URI. It has been accepted for inclusion in Marine Affairs Faculty Publications by an authorized administrator of DigitalCommons@URI. For more information, please contact digitalcommons-group@uri.edu. 
Title:

A METHOD TO ESTIMATE CLIMATE-CRITICAL CONSTRUCTION MATERIALS APPLIED TO SEAPORT PROTECTION

Short Title:

ESTIMATING CLIMATE-CRITICAL RESOURCE DEMAND

\title{
Authors:
}

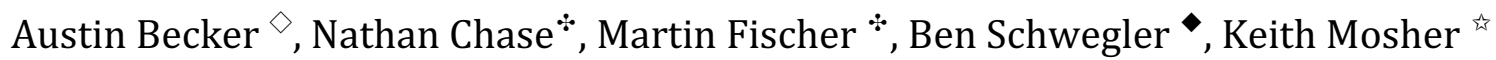

\section{Author affiliations:}

$\diamond$ Department of Marine Affairs, University of Rhode Island, Coastal Institute Room 213, 1 Greenhouse Road, Suite 205, Kingston, RI 02881

$\because$ Nathan Chase, PE- RMC Water and Environment

- Ben Schwegler, PhD, Civil and Environmental Engineering, Stanford University

$\because$ Martin Fischer, PhD, - Civil and Environmental Engineering, Stanford University

* Keith Mosher, MS- Mosher Consulting/Stanford University

\section{Corresponding author:}

Austin Becker, PhD

Department of Marine Affairs

University of Rhode Island, Coastal Institute Room 213, 1 Greenhouse Road, Suite 205, Kingston, RI 02881

e: abecker@uri.edu | p: 401-874-4192 | f: 401-874-2156

\section{Cite as:}

Becker, A., Chase, N.T.L., Fischer, M., Schwegler, B., Mosher, K. (2016) A method to estimate climatecritical construction materials applied to seaport protection. Global Environmental Change, 40, 125-136,DOI 10.1016/j.gloenvcha.2016.07.008, ISSN 09593780.

\begin{abstract}
Climate adaptation for coastal infrastructure projects raises unique challenges because global-scale environmental changes may require similar projects to be completed in many locations over the same time frame. Existing methods to forecast resource demand and capacity do not consider this phenomenon of a global change affecting many localities and the resulting increased demand for resources. Current methods do not relate to the most up-to-date climate science information, and they are too costly or too imprecise to generate global, regional, and local forecasts of "climate-critical resources" that will be required for infrastructure protection. They either require too much effort to create the many localized designs or are too coarse to consider information sources about local conditions and structure-specific engineering knowledge. We formalized the concept of a "minimum assumption credible design" (MACD) to leverage available local information (topography/bathymetry and existing infrastructure) and the essential engineering knowledge and required construction materials (i.e., a design cross-section template). The aggregation of the resources required for individual local structures
\end{abstract}


then forecasts the resource demand for global adaptation projects. We illustrate the application of the MACD method to estimate the demand for construction materials critical to protect seaports from sea-level-rise-enhanced storm surges. We examined 221 of the world's 3,300+ seaports to calculate the resource requirements for a coastal storm surge protection structure suited to current upper-bound projections of two meters of sea level rise by 2100 . We found that a project of this scale would require approximately 436 million cubic meters of construction materials, including cement, sand, aggregate, steel rebar, and riprap. For cement alone, $\sim 49$ million metric tons would be required. The deployment of the MACD method would make resource forecasts for adaptation projects more transparent and widely accessible and would highlight areas where current engineering knowledge or material, engineering workforce, and equipment capacity fall short of meeting the demands of adaptation projects.

\section{Acknowledgements}

We are grateful for input and guidance provided by our colleagues, including: Dr. Miguel Esteban, Dr. Michael Lepech, David Newell, Kyle Johnson, Eric Kretsch, Robert Duncan McIntosh, Cossel Chang, Dr. Christopher Baxter, and Dr. Robert Nicholls. We are also grateful for funding support from the Woods Institute for the Environment at Stanford University. We thank the anonymous reviewers of this paper for their thoughtful comments and suggestions.

\section{Introduction}

Scientists expect global sea level rise to range from 0.6 to 2.0 meters by 2100 (Horton et al., 2014; Parris and Knuuti, 2012; Rahmstorf, 2010) and some project an upper bound of 4.3 meters of rise by 2200 (Vellinga et al., 2008). Even a small amount of sea level rise can have major impacts on storm surge heights and associated flooding (NRC, 2010). Recent studies also found the number of strong (Cat 3-5) hurricanes in the Atlantic basin are likely to double in a warmed-climate scenario (Bender et al., 2010). These dramatic climate changes projected for 2100 and beyond may result in a worldwide competition for adaptation resources on a scale never seen before. Individuals and organizations will likely implement adaptation measures, such as constructing storm barriers to protect the world's major coastal seaports (NGIA, 2014). Such adaptation solutions are often discussed when decision makers think about long-term solutions to reduce risk from storm impacts (Blodget and Wile, 2012; J. Dronkers et al., 1990; Lonsdale et al., 2008). These types of projects will place simultaneous constraints on natural and manufactured resources, construction equipment, skilled labor, engineers, and project managers. Current estimating methods are not adequate for global and regional estimates of the demand for basic resources like aggregate, sand, cement, specialty ships, and equipment like dredges, and coastal engineers. We call such resources "climate critical" and suggest that, occasionally, estimates of the demand for climate critical resources should be made to determine whether there are sufficient resources given the prevalent designs of protection structures. 
Researchers have already generated estimates of the cost of adaptive structures for the U.S. (Aerts et al., 2014; Neumann et al., 2011) and at a global scale (Nicholls et al., 2010) for a wide variety of structures (Jonkman et al., 2013). These studies assume that the necessary resources will be available, should the funding be in place to carry out such projects. However, no such estimates of potential construction resource demand have been conducted to test this assumption against the projected supply.

Attempting a global estimate of climate-critical resources, which are typically under private control, necessarily raises a question of cumulative effects-which any one actor acting in self-interest would not necessarily consider. The built-in incentive of cost-efficient operations for most seaport managers virtually guarantees that all the actors will delay construction until the last responsible moment (Becker et al., 2013). In this light, we are reminded of the assumptions made by individual actors in the "credit risk business" pre2008 and the assumptions made by individual actors planning for climate adaptation today. In the case of the credit risk market, actors assumed that individual risk was trivial because of the enormity of the global market. They did not consider that the cumulative effect of all the individual risks could actually deplete the global market, which, in hindsight, is exactly what happened. In our case, every city or seaport may estimate their own individual resource demand, correctly assuming the trivial strains each may place with respect to the global market. This assumption may be faulty because it does not consider that the cumulative effect of the individual projects could be large.

Estimating construction resources on a global and regional scale poses unique challenges, the most obvious of which is the site-specific nature of infrastructure design. Resourcedemand estimates for necessary materials would normally emerge from individual designs of required adaptation structures, such as breakwaters and flood walls. Best practice engineering design methods require extensive site data, compliance with local standards and regulations, and multi-stakeholder performance criteria (Goda, 2000; Puertos del Estado, 2002; Thoresen, 2003). On a global scale, however, estimating construction resources required by individual designs would be a gargantuan task. For example, for a large infrastructure project such as developing a coastal defense system for a single port, the cost of a preliminary engineering design is typically on the order of $1-5 \%$ of the capital cost for construction (specific figures are generally proprietary, but see for example (TCRP, 2010)). Following Hurricane Katrina, five years were required for a design-build approach to complete the 1.8-mile long Inner Harbor Navigation Canal Surge Barrier in New Orleans at a cost of approximately $\$ 1.1 \mathrm{~b}$ (USACE, 2013), representing thousands of labor hours of skilled planners, engineers, scientists, and technicians. Assuming that $1 \%$ of this cost was required to complete a preliminary design and cost estimate, at an average professional staff fee of $\$ 200 /$ hour this would represent 55,000 hours (which equates to 26 staff working full-time for a year).

While sufficiently accurate for budgeting and decision-making for individual projects, the method of forecasting resource demands from conceptual engineering designs of individual protection structures is too time-consuming to complete a global estimate. In our example of seaport protection, this effort includes agreement on forcing functions (i.e., wave energy, surge heights, tidal ranges), geotechnical design, design lifespans, and maintenance criteria 
in addition to condition assessment of existing structures (USACE, 2008). At the other end of the spectrum of estimating methods, conceptual, order-of-magnitude estimating methods reduce a structure to one or a few variables only (e.g., length of the protection structure) leaving out variables that are critical to estimate resource demand (e.g., depth of the structures and optimal alignment) (Hinkel et al., 2012). While quick, this method leads to results that are too inaccurate for a credible prediction of resource demands for adaptation structures. In summary, existing global demand estimation techniques are either too costly to apply or too inaccurate to understand the potential scale of this construction challenge. Against this background of current engineering practice, researchers seeking a global-scale estimate of construction resources face the tradeoff between simplifying assumptions and accuracy.

We show here a novel technique that addresses this tradeoff. We call the technique "minimum assumption credible design" (MACD). The intuition behind the approach is to combine engineering knowledge with easily available local data to minimize the effort required to design a structure that could protect an area while improving the accuracy of global estimates of materials required for adaptation structures. The approach relies on a MACD for coastal protection structures to estimate an order-of-magnitude demand of construction materials. The remainder of the paper explains the MACD approach by applying it to estimate the materials required to protect the world's most important seaports.

\section{Port adaptation and sea level rise}

The MACD approach is best described by explaining its application for a specific resource prediction challenge. We selected the estimation of the materials required to protect the most important seaports as the application area. We first highlight the importance of protecting these seaports and then describe the MACD method.

\subsection{Why Seaports?}

In its most recent report, the Intergovernmental Panel on Climate Change (IPCC, 2014) found that over US\$3 trillion in port infrastructure assets in 136 of the world's largest port cities are vulnerable to weather events and that, "ports will be affected by climate changes including higher temperatures, SLR, increasingly severe storms, and increased precipitation" (p. 675). As projected changes in sea level and storm intensity progress through this century and beyond, many coastal decision makers, particularly those with responsibility for port operations and development, will likely implement transformational adaptation strategies (Esteban et al., 2014; Kates et al., 2012) such as one of three major adaptation solutions: elevate, defend, or retreat (Aerts et al., 2014; Cheong, 2011; Kates et al., 2012). Elevating a port typically entails filling the port lands to raise them above the floodplain, reconstructing facilities at the new elevation, and designing a system to accommodate the difference in heights between the water level and the port infrastructure (MSPA, 2007). Defending a port entails construction of a coastal protection solution, such as a caisson breakwater, often with floodgates or locks to allow for the passage of ships 
(Dircke et al., 2012). In areas where adjacent land is not available for development, seaports can expand by filling in submerged land to a sufficient elevation that will also protect existing infrastructure. Retreat will likely be the option of last resort because adjacent hinterland areas are typically not vacant or available for relocation, and regional economies depend heavily on their local port. Unless a protected deep river or estuary is available, most seaports will likely either occupy their current location or be abandoned, perhaps in favor of consolidation into a larger regional "super-port". Regardless of which strategy local decision makers choose, climate change adaptation through elevation, defense, or re-construction of infrastructure will require vast amounts construction resources. Given these strategies, we were curious about the materials required to protect seaports and focused the pilot study on the world's seaports for the following five reasons:

1) Seaports sit on the front lines of coastal climate change. Many seaports are located in areas most exposed to natural disasters (Becker et al., 2012). Mean sea level (MSL) rise, higher storm surges and river floods (Jonkeren et al., 2013; Tebaldi et al., 2012; Von Storch et al., 2008), increased tropical storm intensities/destructiveness (Elsner et al., 2008; Emanuel, 2005), and potential changes in wave regimes (IPCC, 2012) could cause significant damage and operational delays at seaports (EQECAT Inc., 2012; Haveman and Shatz, 2006; PANYNJ, 2012). These extreme events cause coastal inundation/erosion, wind hazards and inland floods that can disrupt entire transportation networks (USCCSP, 2008). Many seaports have been hit directly by tropical storms, with damages totaling in the billions of dollars (Blake et al., 2011). In the U.S. for example, Hurricane Katrina caused $\$ 100$ million in damages to Mississippi's ports alone (PEER, 2006), and Superstorm Sandy shut down the Port of New York/New Jersey for over eight days (PANYNJ, 2012).

2) Ports play a critical role in global and local commerce and fulfill a wide variety of functions for the local, regional, and global economy (AAPA, 2015; Baird, 2004; Goss, 1990). They provide jobs, facilitate trade, and serve as critical links between the hinterlands (back region from which goods originate or to which they are destined) and the forelands (seaward region from which goods originate or to which goods are destined).

3) As critical infrastructure, seaports are difficult to relocate. They require deep water, intermodal connections for rail and road, and some amount of protection from the elements . Global trade routes evolved around the network of ports, and even a short-term loss of port capacity (e.g., due to a climate-driven natural disaster) causes local and global ripple effects in logistics and trade-dependent industries (Losada and Benedicto, 2005; Reeve, 2010; Thoresen, 2003).

4) Delineating seaport infrastructure from an aerial map presents fewer challenges than delineating other types of coastal uses (e.g., cities, neighborhoods, commercial districts, or sewer networks). Seaport infrastructure (including wharves, piers, cranes, tanks, laydown areas, and warehouses) can be identified from aerial and satellite imagery, a necessary step in our method. Although seaports represent just one important coastal use amongst many, making subjective decisions about which other coastal areas warrant protection and which do not falls outside the scope of this pilot.

5) Design guidance for a number of coastal protective structures can be adapted into a parametric model, allowing for estimates of material requirements (USACE, 2008). Our model depends on the use of structural designs that are appropriate for a wide range of local conditions and are conducive to developing resource estimates.

Page 5 


\section{The MACD Approach}

The MACD approach as applied to seaports consists of the following five steps:

\section{Step 1. Develop the "Minimum Assumptions for Credible Design"}

The MACD approach relies on a minimum number of assumptions with respect to geophysical location, land use, and structure designs.

Step 1 - Develop geophysical and land-use criteria.

We begin with the following assumptions:

- $\quad$ Current seaport configurations would not change.

- $\quad$ A new structure would be completed for each seaport (i.e., no retrofits).

- Port areas to be protected can be inferred from satellite or aerial imagery.

Step $1 b$ - Select credible onshore and offshore structure designs

Conventional seaport and harbor designs use a probabilistic assessment of a "maximum credible adverse condition," requiring joint analysis of design cases for the drivers of waveovertopping flooding and still-water level flooding (Pullen et al., 2007b). Given that the objective of determining a global resource demand estimate precludes intensive sitespecific data collection, we prepared a three-part parametric coastal-protection structure design template based on existing engineering guidelines (USACE, 2000). Each structural segment's dimensions are calculated based on defending from still water level flooding, resulting from the storm surge heights expected at each seaport, not including wave action plus a $2 \mathrm{~m}$ SLR (see Appendix C for details). The wave component was excluded, as it was assumed that the seaports studied would have existing structures in place to shelter the berths from present-day wave overtopping, if required. For simplicity, we have excluded the impact of SLR on increasing the height of waves, of increased extreme wind speeds that in turn would increase the storm surge levels, and of subsidence that may exacerbate flooding vulnerability (Muis et al., 2016).

For each design template, we calculated only materials of construction critical for most heavy civil and maritime infrastructure projects: sand, gravel, quarry-run stone, riprap, concrete, and steel. To retain simplicity, we did not include a floodgate or lock system to allow for ship passage in this design, though if actually constructed such a system would be required. The design cross-sections for the following three structure types are shown in Figure 1, for which each component has a defined construction material. 


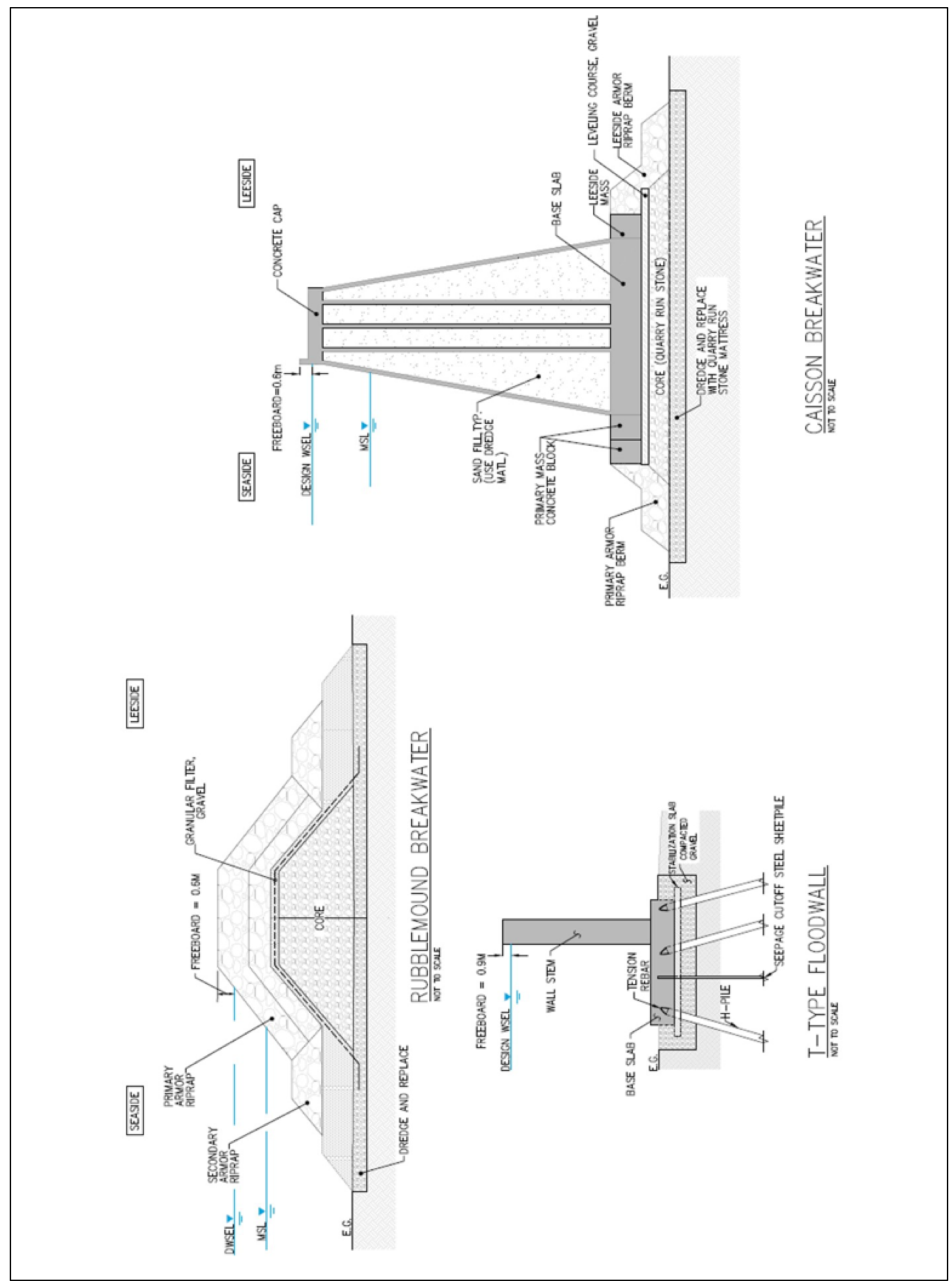

Page 7 
Figure 1 - Floodwall, Rubblemound Breakwater, and Caisson Breakwater designs (see also Appendix C)

The onshore portions of the alignment (i.e., where existing grade is higher than mean sea level) consist of a T-Type Floodwall (USACE, 2008). This design template was developed from United States Army Corps of Engineers (USACE) EM 1110-2-2502 and "Hurricane and Storm Damage Risk Reduction System Design Guidelines" (USACE, 2012).

The offshore portions of the alignment, up to a structural height of $15 \mathrm{~m}$, use a rubblemound breakwater.

The offshore portions of the alignment, for structural heights greater than $15 \mathrm{~m}$, use a caisson breakwater (USACE, 2008). The latter design templates were developed from USACE EM-1110-2-1100 and details can be found in Appendix C.

Step 1c - Determine design constraint assumptions

We constrained the modeled structural alignment to a maximum depth of 60 meters, based on a survey of existing structures. The world's deepest breakwater, the Kamaishi breakwater in Japan, is 63m deep and $8 \mathrm{~m}$ above mean sea level (Mimura et al., 2011). Although existing techniques conceivably allow structures to be constructed at greater depths, (e.g., EurOtop guidance provides for caisson structures in depths greater than $100 \mathrm{~m}$ (Pullen et al., 2007a)), the 60 meter constraint provides a reasonable assumption in keeping with the overall approach.

We determined the required structure crest elevation (SCE) to protect against a flood event at the port location by calculating a design water surface elevation (DWSEL) using tide and surge probability data (see Appendix C for details), as follows:

$$
\begin{aligned}
& D W S E L=S S+S L R \\
& S C E=D W S E L+F B
\end{aligned}
$$

$D W S E L=$ Design water surface elevation or "assumed flood level"

$S S=$ Storm surge height derived from $.01 \%$ annual probability height as found in the DIVA database (Vafeidis et al., 2008), does not include wave action (See Appendix C for details)

$S L R=$ Assumed sea level rise (our pilot study uses a SLR of $2 \mathrm{~m}$ )

$\mathrm{FB}=$ Additional freeboard height of $.9 \mathrm{~m}$ for onshore structures (based on the USACE minimum freeboard of 3 feet for levees) and .6m for offshore structures (which are expected to be more tolerant to modest overtopping)

$\mathrm{SCE}=$ Structure Crest Elevation. This SCE is input into a calculation that selects the appropriate design template and then scales each of that cross-section's structural component material areas to reach the SCE. The various cross-sectional areas are then multiplied by the length between topographic/bathymetric grid points to obtain the volume of construction materials for that segment. 
This process is repeated along the length of the structure to obtain an overall volumetric estimate by type of construction material (for more details, see Appendices B and C).

\section{Step 2. Select representative seaports}

There are some 3,300+ seaports in the world (NGIA 2014), so for the purpose of method development, we sampled a subset of seaports based on economic value, population served, and data availability. We included the top 100 coastal seaports by tonnage volume and container throughput of twenty-foot equivalent units (TEUs) in 2011 (AAPA 2011). We also included all coastal seaports identified in the World Port Index (NGIA 2014) that were located within or nearby a metropolitan area with a population of approximately one million or more (Nordpil, 2009). This resulted in 221 seaports (see Figure 2 and Appendix A for the list or seaports included).

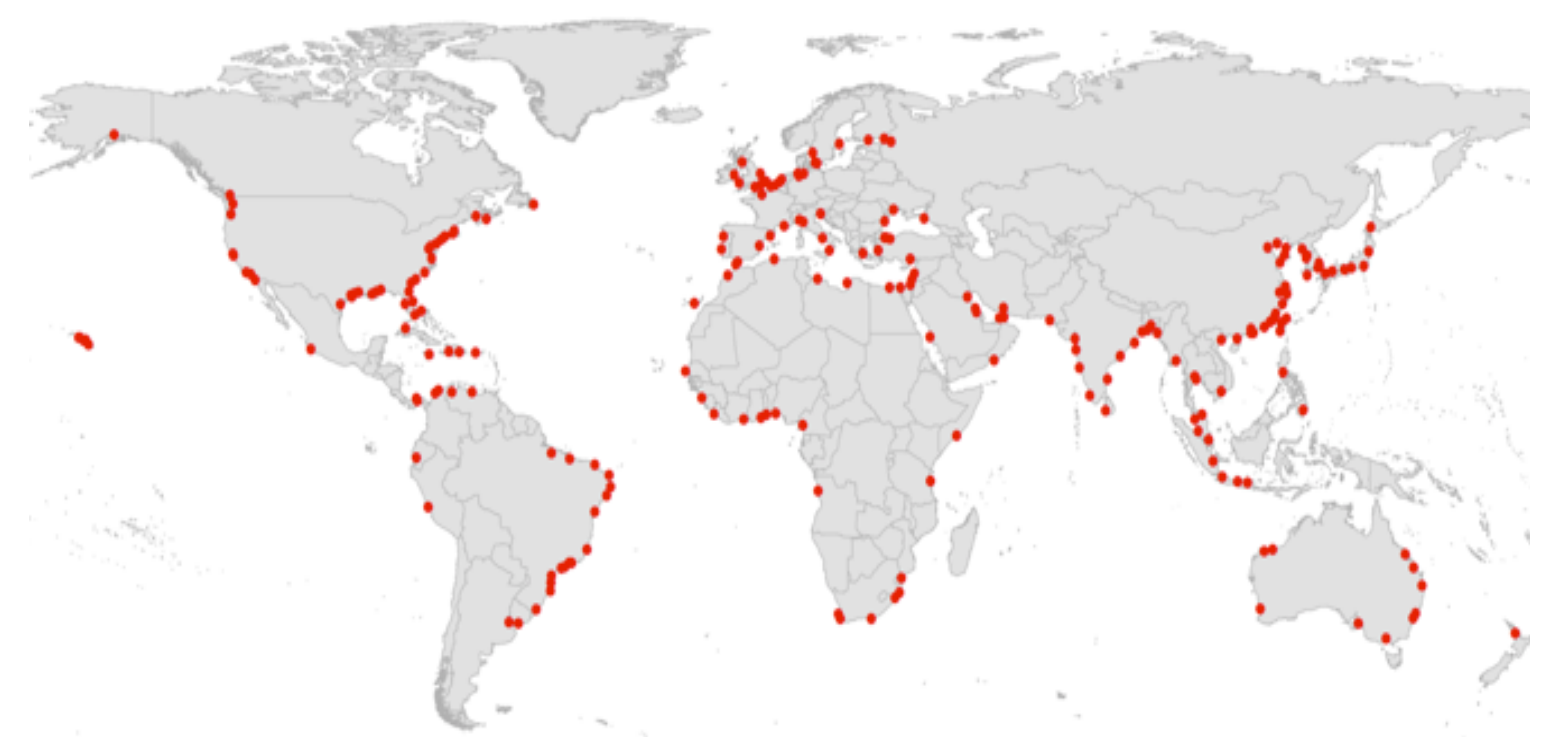

Figure 2 - Map of 221 coastal ports that are in the top 100 by throughput (2011) or serve a population greater than 1 million.

\section{Step 3. Determine affected areas in representative seaports}

To delineate the areas to be protected in each of the 221 seaports, we created a "port polygon" that encompasses major seaport infrastructure identified by visual analysis of aerial imagery available in Google Earth, including shipping berths, large tanks, shipping cranes, warehouses, laydown areas, and access points. The red polygon in Figure 3 shows the port infrastructure in Kingston, Jamaica, as an example. For simplicity, no attempt was made to consult property records or other maps to determine exact boundaries or differentiate between various ownership entities. 


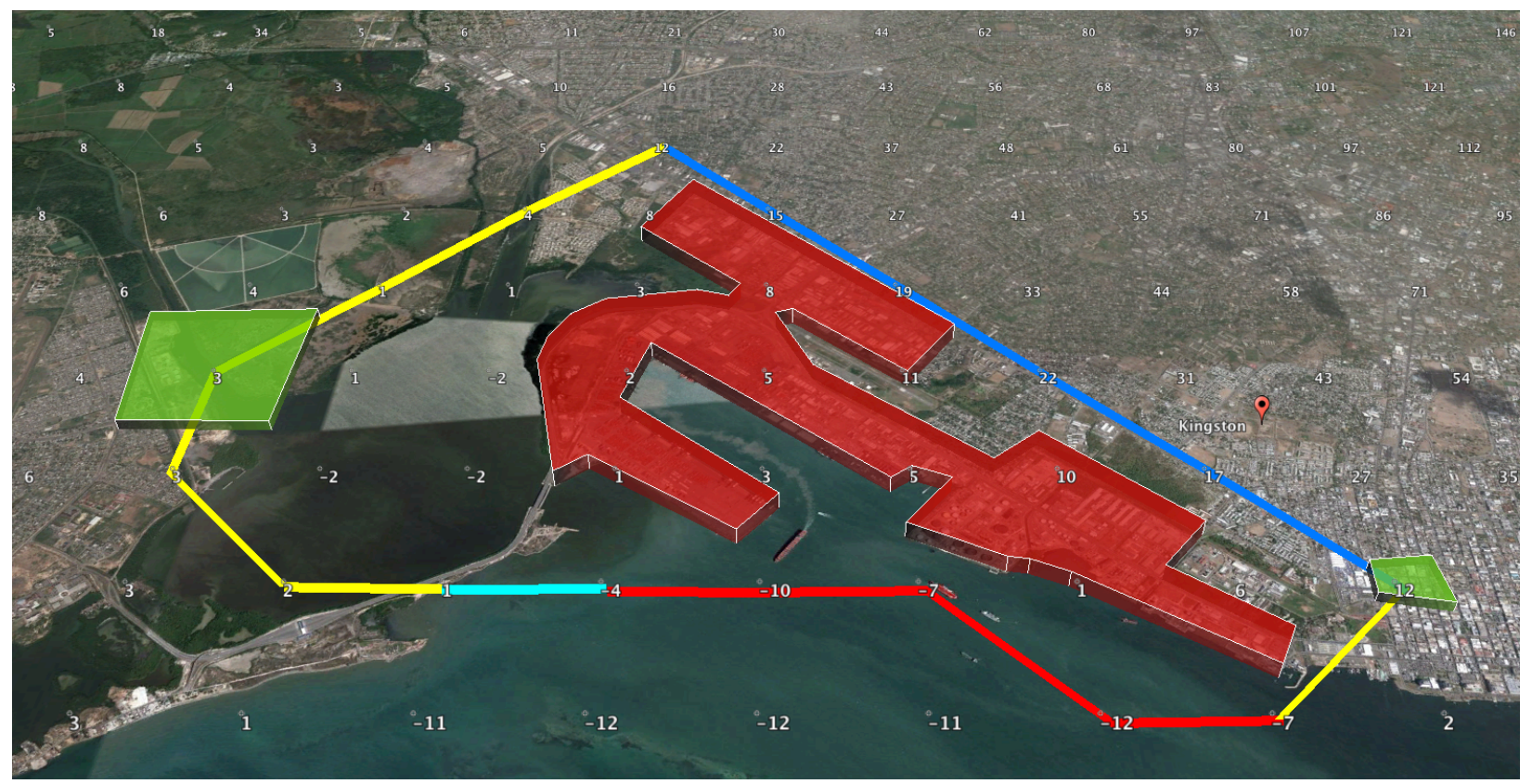

Figure 3 -- Example of port protector model run for Kingston, Jamaica, showing elevations in meters and structure selections. Numbers represent elevation and bathymetry data points (meters). Red polygon = port polygon; Green polygon = start/end polygon, Dark blue = natural elevation (no structure needed), Yellow $=\mathrm{T}$ Floodwall, Red = Caisson Breakwater, Light Blue = Rubblemound breakwater

\section{Step 4. Create model Start/End abutment locations}

Once the protected port area polygon is identified, terminating abutment locations are manually chosen using elevation data available in Google Earth (USGS, 2004). These "start/end polygons" (green polygons shown in Figure 3) are located at or above the required structure crest elevation (SCE).

\section{Step 5. Calculate resource requirements via port protector}

To automate the calculation of the materials required, we implemented a software tool we called the Port Protector. The tool first finds the path between the start/end polygons that minimizes the volume of construction materials required, while enclosing the port polygon described above. We used the SRTM-30 global dataset of bathymetry and topography elevation data available through Google Earth (USGS, 2004), and an optimal structural alignment path derived using a shortest path, weighted edge, graph-search algorithm (See Appendix B for information on data and Appendix C for information on the algorithm).

The Port Protector software calculates the construction material volume for each structure segment, which is used as the weighting factor to connect each set of two bathymetry or elevation points along the alignment path. The volumes for each of the three different design structure choices are compared to find the lowest volume alignment, first on the offshore side of the seaport infrastructure (comprising caisson and rubblemound breakwater designs), and then again around the onshore side (comprising the T-floodwall design). As seen in the example of Kingston, Jamaica, depicted in Figure 3, the yellow lines represent paths that require the T-floodwall structure, the red lines represent caisson breakwaters, the light blue represents rubblemound breakwaters, and the dark blue lines 
represent areas where no structure is necessary, as the natural elevation provides adequate protection. We did not make any decisions about the model path with respect to other factors (e.g., environmental resources, other infrastructure, populated areas, historic resources, intermodal connections). After manually verifying each seaport's protective structure path to ensure no egregious errors, the Port Protector Model calculates total lengths, volumes, and materials required and aggregates totals, as described in the next section.

\section{Estimates of resource demand using the MACD approach to protect seaports}

Becker et al. (Becker et al., 2012) show a 2-meter sea level rise (SLR) as the threshold at which all seaport managers surveyed feel that they would be required to take action to protect their facilities. Several published estimates (Rahmstorf, 2010; Vermeer and Rahmstorf, 2009) set a 2-meter SLR by 2100 as the upper bound, thus we used this as the basis for the application of the minimum assumption credible design (MACD) approach to estimate the main construction materials required to protect the 221 seaports. By calculating the shortest and shallowest alignment for the protection structure and applying a parametric coastal protection design across the alignment, the Port Protector generates required material quantities that are aggregated to form global estimates for constructing defenses for the world's seaports from storm surge associated with a hypothetical 2-meter sea level rise.

In total, $3,600 \mathrm{~km}$ of structure would be required to protect the world's top 221 seaports (Figure 4). This would equate to a single structure spanning from Los Angeles (CA) to Chicago (IL). By length, 71\% of the structures would be built offshore. However, as seen in Figure 5 , about $92 \%$ of the materials required would be used in the offshore structures because the structural height required for the onshore portions to reach the DWSEL is significantly less than the offshore portions which. 


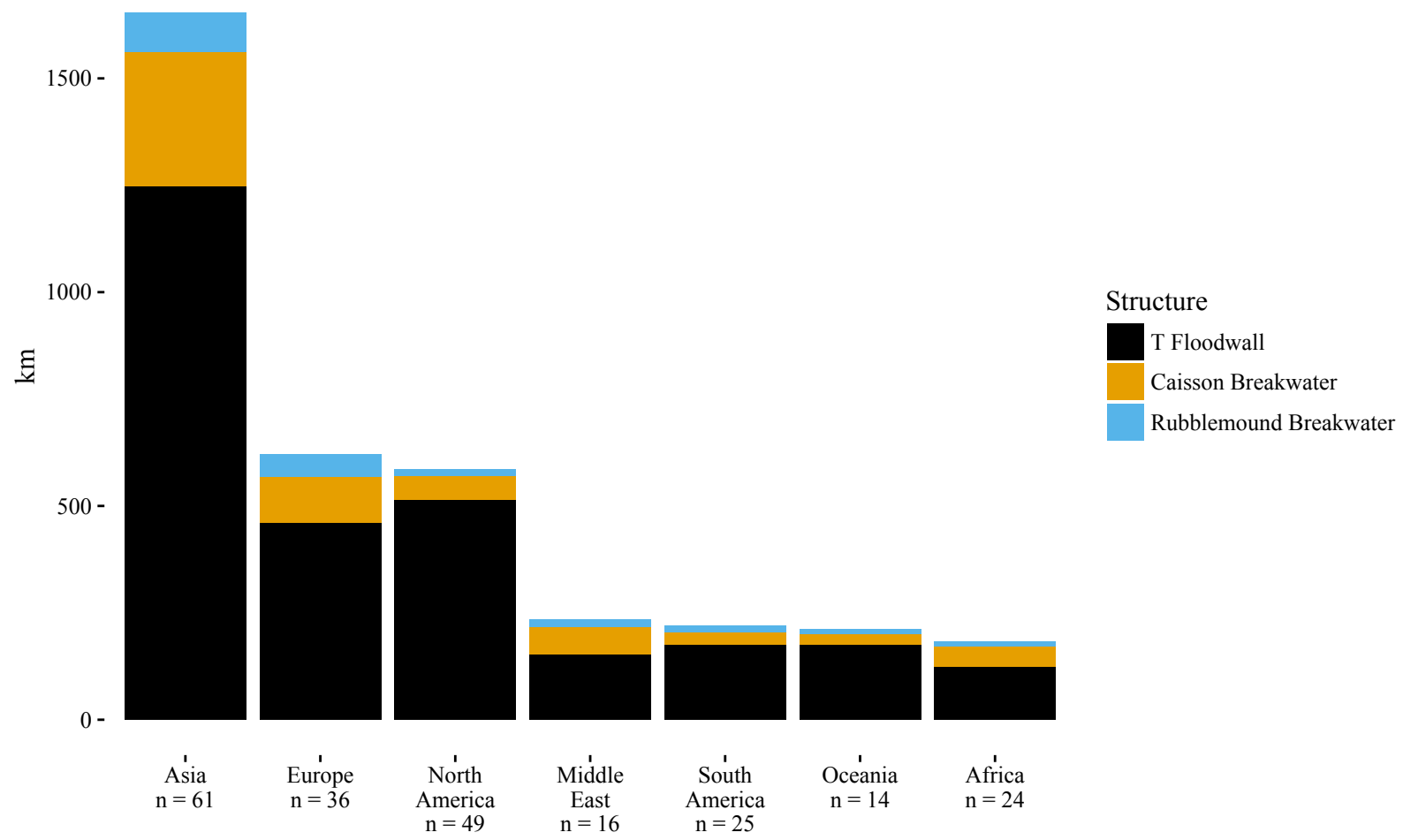

Figure 4 - This graph depicts the total linear kilometer of structures needed to protect seaports in each of the seven global regions studied. In aggregate, $3,600 \mathrm{~km}$ of structure would be required.

When the volume of materials required to construct these structures is aggregated, we found that $436 \mathrm{M}$ cubic meters of construction materials would be required to protect the 221 seaports in our study. This includes all materials for the three structure designs used in the model. Figure 5 shows the quantities of materials required by material type. By volume, sand, stone, and concrete are the three main materials required. The total volume of materials required would equate to about 7 Three Gorges Dams (based on 65M cubic meters of material used in the construction of the Three Gorges Dam on the Yangtze River in China) (Chinese Embassy, 2014). The 143M cubic meters of concrete required alone is equivalent to building about 52 Hoover Dams (based on 2.74M cubic meters of concrete used in the construction of the Hoover Dam on the Colorado River in the United States). 


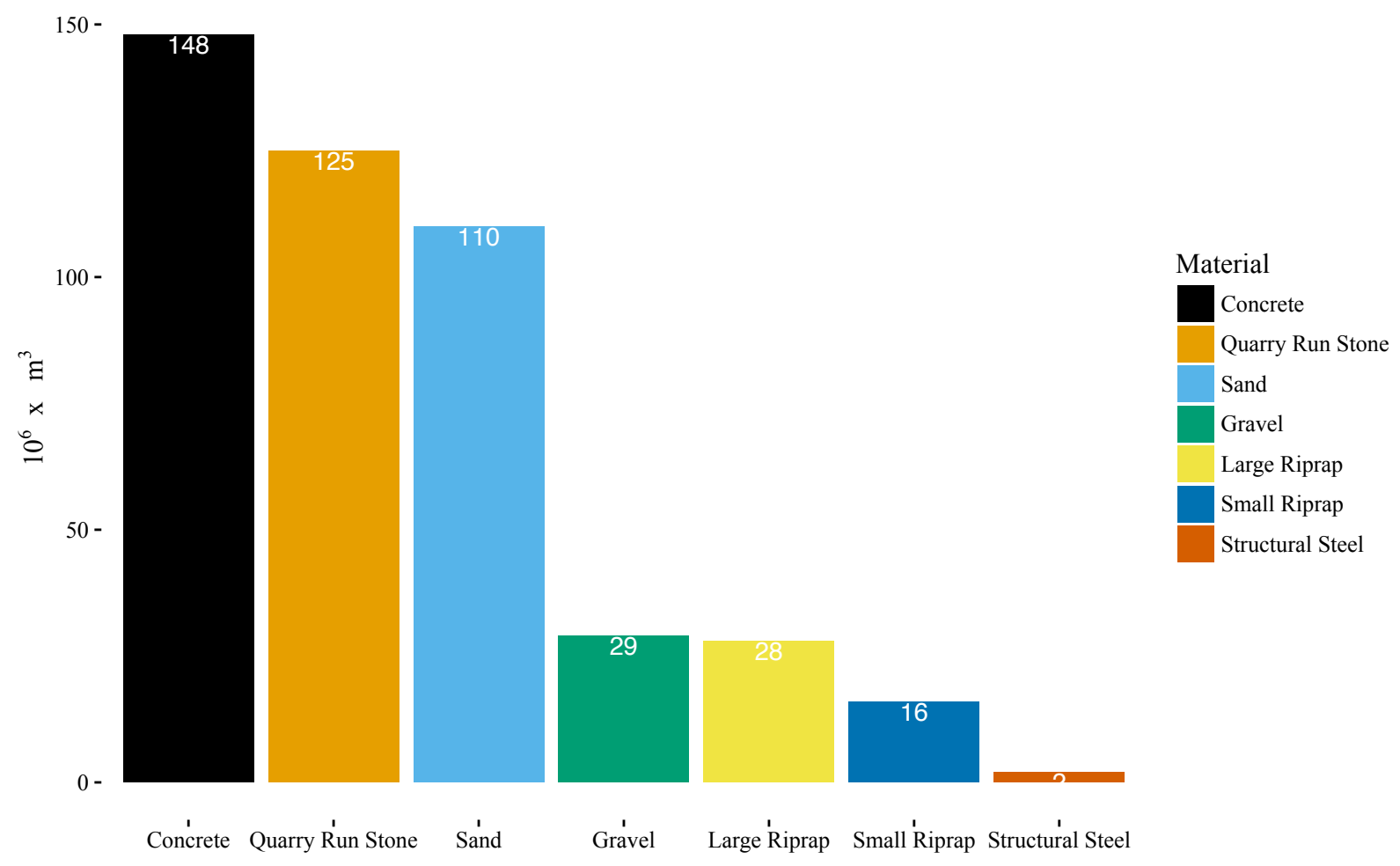

Figure 5 - Global volumes of various construction materials required to protect 221 seaports

Figure 6 shows the sum total amounts of all materials for the seaports in each region. Asian seaports alone require $47 \%$ of all materials, even though only about a quarter of the most important seaports in our study are in Asia. Protecting the 36 most important European seaports will require more materials than protecting the 45 most important North American seaports. Thus, the number of seaports in a region alone is not a good indicator of the amount of materials required to protect that region's maritime infrastructure. Other site-specific factors-which the Port Protector does account for following the MACD approach-play a major role in determining the construction material quantities such as port area extent, length of waterfront encompassed, surrounding topography, and offshore depths. 


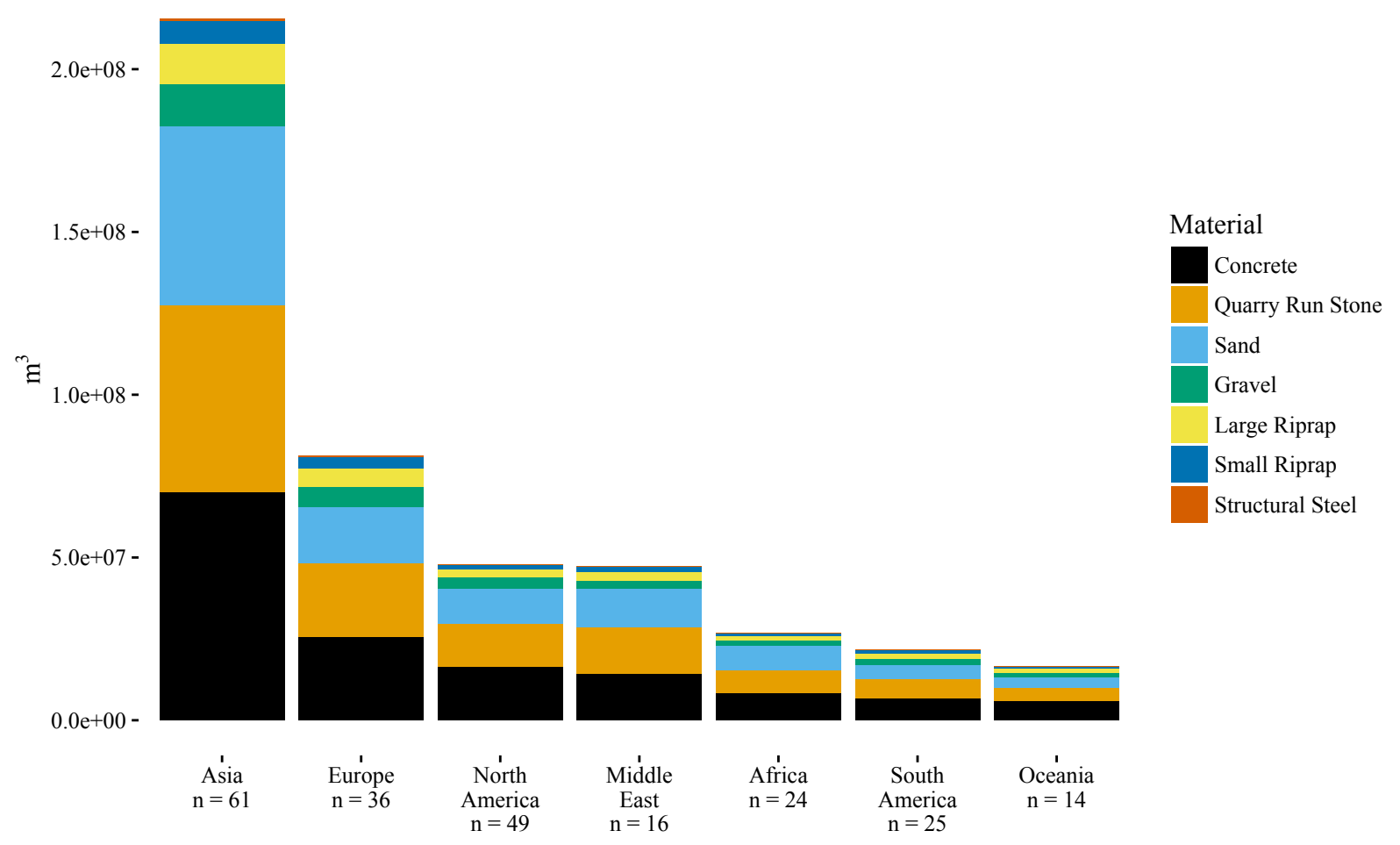

Figure 6 - Total volume of construction materials required to construct three types of protective structures around 221 seaports (by type of material and by region)

\subsection{Resource demand vs. supply}

Our method generates an estimate of the demand side of the supply/demand equation for resources required to construct protective structures around seaports. The nature of the global competition for resources takes on added significance when demand exceeds supply. Fu et al. (Fu et al., 2013) show that estimating global capacity for the supply of climatecritical resources also remains a significant challenge due to limited data availability, lack of uniformity, and other complications. Here, we use the results from Fu et al.'s study of global cement production capacity to examine the supply/demand balance for cement. Many of the resources required in civil construction (e.g., aggregate, pumping, batching, labor, construction equipment) are proportional to the cement used, though globally or regionally, other materials, human resources, or construction equipment may be the capacity constraint (Peduzzi, 2014). Capacity utilization for cement manufacturing is typically high in all regions of the world (Figure 8), thus we analyzed cement production capacity and compared the results to our estimate of new cement demand that would be generated by an effort to protect 221 seaports.

As seen in Figure 5, 148M cubic meters of concrete will be required based on our global estimate for seaport protection. Each cubic meter of concrete consists of approximately $345 \mathrm{~kg}$ of cement (Kosmatka et al., 2011); thus, our global estimate for cement required to build out the protective structures comes to $49 \mathrm{M}$ metric tons of cement, as depicted in (Figure 7) and broken down by region. 


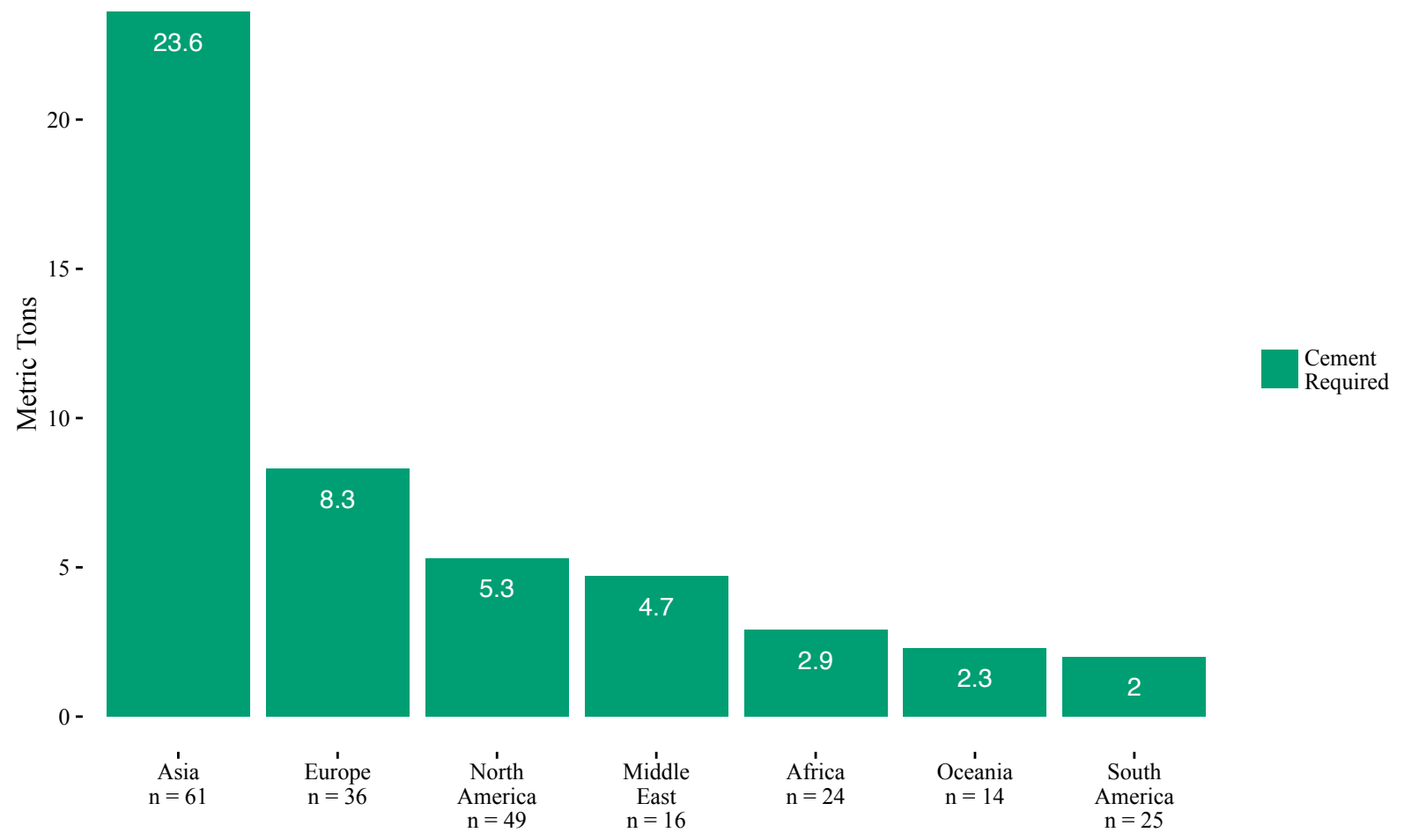

Figure 7 - Showing cement required by region and a total of 49 metric tons of cement required to construct protective structures around 221 seaports, with Asia requiring the most cement at 23.6 metric tons.

With unused, expandable global cement production capacity of about 1.1B tons per year, the cement required to protect just 221 of the world's 3,300+ coastal seaports (NGIA, 2014) represents about $4 \%$ of the available estimated unutilized annual production capacity for cement, as calculated for 2008.

As depicted in Figure 7, Asia alone would need 23.6M metric tons of cement to protect its 61 most important seaports. In 2007-09, it used approximately 69\% of its production capacity (Figure 8), leaving $31 \%$ of its potential capacity to devote to adaptation projects such as armoring seaports. 


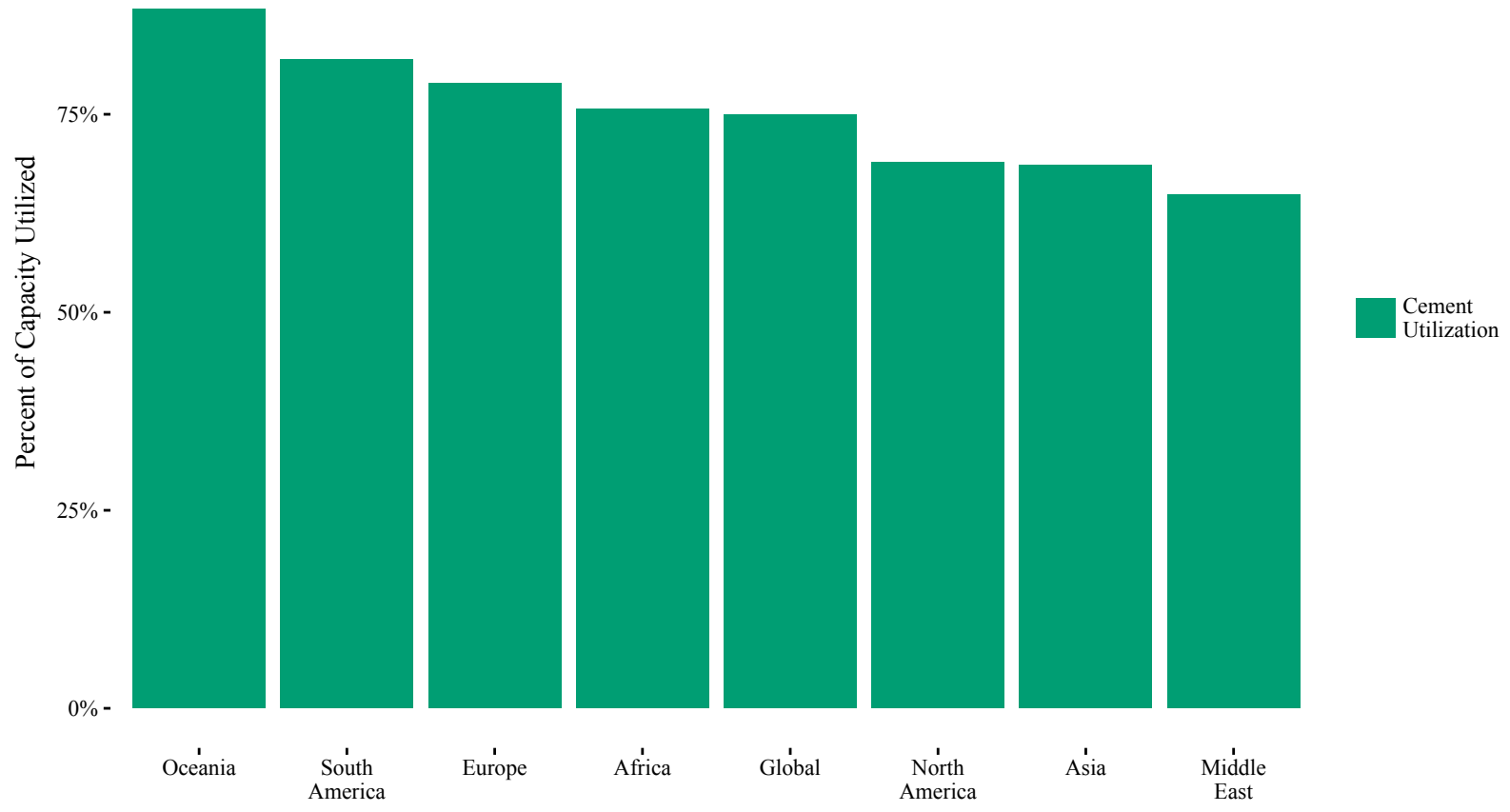

Figure 8 - Showing average annual cement capacity utilization by region (2007-2009) with 95\% confidence interval (Fu et al. 2013).

As other global resource capacity estimates become available, the method proposed in this paper could allow engineers and policymakers to quickly check for the largest gaps in capacity to meet expected demand for climate adaptation construction.

\subsection{Limitations of the Case Study}

The difficulty of producing a global-scale estimate required us to make a number of assumptions that reduce the accuracy of our results. One could, of course, point to a number of issues with respect to our chosen design. For example, each seaport would require at least one opening to allow for the passage of ships (e.g., a strategically placed gap based on coastal hydrodynamics, a floodgate, or lock structure), thereby increasing the complexity and construction materials required for the project and potentially decreasing shipping capacity by creating a navigational bottleneck. Also, the pathway that our design follows does not consider any other variables outside of optimization of materials. Thus, it is most likely not an optimal alignment to mitigate local wave dynamics and may cut through other important infrastructure, densely populated areas, critical habitat, or historic landmarks. There would be important environmental considerations should one want to actually construct such a project. Large linear projects have a huge array of other secondary impacts, let alone an enormous price tag. We also do not consider the costeffectiveness of our design structure versus any other option, nor the potential to retrofit existing structures. Lastly, shipping volumes are expected to grow significantly over the coming century and our model does not account for any resulting expansion (or 
consolidation) of seaport facilities (Allen, 2012). Some seaports would likely choose other adaptation solutions, such as elevating their land, consolidating operations and abandoning some infrastructure, or simply relocating up a river system and out of harm's way. Our method simply calculates a reasoned resource requirement for one scenario, without making value judgments on the "best" plan of action to adapt to climate change for the specific context for any individual port. All these site-specific requirements will certainly be considered when such a project will be designed for a port.

Our model can be further developed in terms of accuracy and comprehensiveness. Our method requires global datasets for elevation and bathymetry in order to create a design path optimized for least materials (i.e., shallowest and shortest path). Unfortunately, highresolution data are not available for all locations throughout the world, though we did compare results of our model using both higher and lower resolution data for a selection of ten ports and found comparable results (see Appendix B for discussion of this sensitivity analysis). We thus relied on best-available elevation data to conduct our study. Regional variations in sea level rise and site-specific parameters would necessitate full engineering studies; these additional criteria have been ignored in order to allow for a global approach.

\section{Discussion of the value of the MACD approach}

Engineers, in particular, may be uncomfortable with the concept of a "minimum assumptions for credible design" approach in large part because the engineering profession itself has evolved to manage design risk and design liability by industry best practices and legal/regulatory requirements. Best practice therefore requires a site-specific design tailored to its unique set of conditions and project requirements (Losada and Benedicto, 2005; Thoresen, 2003). However, the quality and quantity of data required for best engineering practice design is simply not available to satisfy questions around global estimates (Hanson et al., 2010; J. Dronkers et al., 1990). The MACD approach presents a solution to this issue by incorporating a selected few design requirements deemed critical (which would also be used in a conventional engineering design together with a significantly longer list of design requirements), while at the same time simplifying the data required to generate a design that can be readily estimated in the context of global capacity.

Of all possible project criteria for protective structures, engineers and designers primarily consider safety, accessibility, and environmental effects (Puertos del Estado, 2002; Thoresen, 2003; USACE, 2008). Specific site locations dictate other criteria, such as the local forcing functions of wave height, wave period, storm duration and surge water level. Additionally, local geomorphology, inland connections, and surrounding land use patterns make each port unique (NGIA, 2014). Creating what amounts to 221 unique designs for the world's most important seaports would require thousands of workhours for engineers, planners, architects, and other construction professionals (OEM, TCRP (Transit Cooperative Research Program), 2010; 2015). Our demand estimate for cement to protect 221 seaports represents $4 \%$ of the amount theoretically available, and this percentage would escalate rapidly if more of the world's 3,300+ seaports were included. Accounting for additional coastal uses that would require protective structures or other constructed adaptation solutions (Jonkman et al., 2013) would further escalate the demand and could 
quickly cause constraints on availability that may outpace the rate at which further production capacity could be added. These additional coastal uses include vulnerable infrastructure, such as power plants, sewage treatment plants, airports, roadways, railways, and bridges. Whole cities may need protection, bringing the resource requirements to levels well beyond capacity.

The methodology presented here could be useful in quantifying this broader set of demands for construction materials anticipated to be used in climate-change response schemes. Conventional planning techniques for infrastructure construction projects take into account design performance, life-cycle costs, constructability, and schedule as the critical limiting factors (World Bank, 2010). However, resource availability may also be a bottleneck, given that local or global supply and production capacity may be insufficient to perform all the work required within an acceptable timeframe and at an acceptable cost. Indeed, cement, aggregate, sand, and steel all come with their own unique limitations in different parts of the world (Peduzzi, 2014). Sand for example, necessary for the construction of breakwaters, may not be available locally for many seaports in the quantities and quality required (Simpson et al., 2005).

The results of this pilot study raise serious questions about constructing coastal protections on a global scale: What will happen to the 3,100+ seaports that are not the world's most important? What will the local resource bottlenecks be? On a global scale, cement may be the limiter, but resources are not well distributed and for a specific site, sand, riprap, or gravel could prove to be a larger bottleneck. If seaports comprise just one part of the urban coast that needs protecting, what is the magnitude of the resource quantities required to protect all the important uses? Will construction resource limitations result in fewer (but far larger) seaports in the future? Will the seaports that are better protected today have a market advantage over those that are more exposed to climate-driven storm impacts? To answer these types of questions, we encourage wider applications of our data and methods for future research that combines engineering, science, economics, and policy in order to begin to address such challenging questions.

\section{Conclusions}

Adapting urban coasts to increased flooding arising from climate change might rely on construction of conventional engineered onshore and offshore barriers, similar to the response of Netherlands to the North Sea flood of 1953 by constructing a series of dams, storm surge barriers, and other structures. Scientists and engineers who provide technical information and designs for adaptation strategies need to contribute to policy and planning discussions to prioritize and allocate climate-critical resources, such as construction materials. Though individual actors and governments may default to a heavy civil infrastructure construction approach as an adaptation solution, a global uncoordinated response of this nature may be unsustainable simply from a resource availability perspective (Peduzzi, 2014). If so, the global community has a window of opportunity to avoid this scenario by developing alternative solutions and new strategies to protect its coastal seaports, cities, and other vulnerable resources. Global estimates for climate-critical resources provide essential data to this emerging global dialogue.

Page 18 
We have made the first such estimate for infrastructure assets critical to one sector of the global economy. Naturally, protecting seaport infrastructure alone comprises but one piece of the adaptation measures necessary for resilience to natural disasters exacerbated by climate change. Other critical infrastructure such as rail, highway, and utilities also face climate-related impacts and will require additional resources. We formalized the MACD method to estimate the resource demand from such adaptation measures. Our initial results suggest that adaptation will be a monumental task and will significantly tax global resource capacity. The results reinforce the necessity for the global community to take significant steps to reduce greenhouse gas emissions and slow the pace of global warming. We hope that the improvement and use of global demand estimates for climate-critical resources can lead to timely capacity development for such resources.

\section{REFERENCES}

AAPA (American Association of Port Authorities), 2011, World Port Rankings 2011, Accessed July 18, 2014, Online at http://aapa.files.cms-plus.com/PDFs/WORLD PORT RANKINGS 2011.pdf.

AAPA (American Association of Port Authorities), (2015) Talking Points U.S. Seaports and Job Creation. http://aapa.files.cms-plus.com/PDFs/U S Seaports and Job Creation 5-12-2015.pdf

Aerts, J., Botzen, W.j., Eamanuel, K., Lin, N., deMoel, H., Michael-Kerjan, E. (2014) Evaluating Flood Resilience Strategies for Coastal Megacities. Science, 344, 473-476.

Allen, C. (2012) Future Ports Scenarios for 21st Century Port Strategic Planning. Journal of Transportation Law, Logistics, and Policy, 79, 89-137.

Baird, A.J. (2004) Public goods and the public financing of major European seaports. Maritime Policy \& Management, 31, 375-391, ISSN 0308-8839.

Becker, A., Acciaro, M., Asariotis, R., Carera, E., Cretegny, L., Crist, P., Esteban, M., Mather, A., Messner, S., Naruse, S., Ng, A.K.Y., Rahmstorf, S., Savonis, M., Song, D., Stenek, V., Velegrakis, A.F. (2013) A Note on Climate change adaptation for seaports: A challenge for global ports, a challenge for global society. Climatic Change, 120, 683-695,DOI 10.1007/s10584-013-0843-z.

Becker, A., Inoue, S., Fischer, M., Schwegler, B. (2012) Climate change impacts on international seaports: knowledge, perceptions, and planning efforts among port administrators. Climatic Change, 110, 5-29,DOI 10.1007/s10584-011-0043-7, ISSN 0165-0009

1573-1480.

Bender, M.A., Knutson, T.R., Tuleya, R.E., Sirutis, J.J., Vecchi, G.A., Garner, S.T., Held, I.M. (2010) Modeled impact of anthropogenic warming on the frequency of intense Atlantic hurricanes. Science, 327, 454-458,DOI 10.1126/science.1180568, ISSN 1095-9203 (Electronic) 0036-8075 (Linking), Online at http://www.ncbi.nlm.nih.gov/pubmed/20093471.

Blake, E.S., Gibney, E.J., Landsea, C. (2011) The deadliest, costliest, and most intense United States tropical cyclones from 1851 to 2010 (and other frequently requested hurricane facts). NOAA/National Weather Service, National Centers for Environmental Prediction, National Hurricane Center, Washington, DC. 
Blodget, H, Wile, R., (2012) Hey, it will only cost \$7 Billion to build a storm surge barrier for New York -Whaddya say?, Business Insider.

Cheong, S.M. (2011) Policy solutions in the US. Climatic Change, 106, 57-70, ISSN 0165-0009.

Chinese Embassy (Embassy of the People's Republic of China in the United States of America), (2014) Some Facts about the Three Gorges Project. http://www.china-embassy.org/eng/zt/sxgc/t36512.htm

Dircke, P.T.M., Jongeling, T.H.G., Jansen, P.L.M., (2012) An Overview and comparison of navigable storm surge barriers, in: United States Society on Dams (USSD) (Ed.), Innovative Dam and Levee Design and Construction for Sustainable Water Management, New Orleans, LA. http://ussdams.com/proceedings/2012Proc/65.pdf

Elsner, J.B., Kossin, J.P., Jagger, T.H. (2008) The increasing intensity of the strongest tropical cyclones. Nature, 455, 92-95, ISSN 0028-0836.

Emanuel, K. (2005) Increasing destructiveness of tropical cyclones over the past 30 years. Nature, 436, 686688, ISSN 0028-0836.

EQECAT Inc., (2012) Post-landfall loss estimates - Hurricane Sandy - Nov. 1, 2012 (Insured Losses: \$10 - 20 Billion; Total Economic Damage: \$30 - 50 Billion).

Esteban, M., Mikami, T., Shibayama, T., Takagi, H., Jonkman, S.N., van Ledden, M. (2014) Climate change adaptation in Tokyo Bay: The case for a storm surge barrier. Coastal Engineering Proceedings, 1, 35, ISSN 2156-1028.

Fu, E., Newell, D., Becker, A., Schwegler, B., Fischer, M. (2013) Is Adaptation Sustainable? A Method to Estimate Climate-Critical Construction Resource Capacity. Construction Innovation: Information, Process, Management, 13, 202-216, ISSN 1471-4175.

Goda, Y. (2000) Random seas and design of maritime structures. World Scientific Pub Co Inc.

Goss, R. (1990) Economic policies and seaports: The economic functions of seaports†. Maritime Policy and Management, 17, 207-219, ISSN 0308-8839.

Hanson, S., Nicholls, R., Ranger, N., Hallegatte, S., Corfee-Morlot, J., Herweijer, C., Chateau, J. (2010) A global ranking of port cities with high exposure to climate extremes. Climatic Change, 104, 89-111,DOI

10.1007/s10584-010-9977-4, ISSN 0165-0009

1573-1480.

Haveman, J.D., Shatz, H.J. (2006) Protecting the nation's seaports: Balancing security and cost.DOI 1-58213120-1, ISSN 1582131201, Online at http://www.ppic.org/content/pubs/report/r_606jhr.pdf.

Hinkel, J., Vuuren, D.P., Nicholls, R.J., Klein, R.J.T. (2012) The effects of adaptation and mitigation on coastal flood impacts during the 21st century. An application of the DIVA and IMAGE models. Climatic Change, 117, 783-794,DOI 10.1007/s10584-012-0564-8, ISSN 0165-0009

1573-1480.

Horton, B.P., Rahmstorf, S., Engelhart, S.E., Kemp, A.C. (2014) Expert assessment of sea-level rise by AD 2100 and AD 2300. Quaternary Science Reviews, 84, 1-6,DOI 10.1016/j.quascirev.2013.11.002, ISSN 02773791.

IPCC (Intergovernmental Panel on Climate Change), (2012) Managing the risks of extreme events and disasters to advance climate change adaptation. Special report of the Intergovernmental Panel on Climate Change, in: Field, C.B., Barros, V., Stocker, T.F., Qin, D., Dokken, D.J., Ebi, K.L., Mastrandrea, M.D., Mach, K.J., Plattner, G.-K., Allen, S.K., Tignor, M., Midgley, P.M. (Eds.), SREX, Cambridge, UK, and New York, NY, USA. 
IPCC (Intergovernmental Panel on Climate Change), (2014) Climate Change 2014: Impacts, Adaptation, and Vulnerability. Part A: Global and Sectoral Aspects. Contribution of Working Group II to the Fifth Assessment Report of the Intergovernmental Panel on Climate Change, in: Field, C.B., V.R. Barros, D.J. Dokken, K.J. Mach, M.D. Mastrandrea, T.E. Bilir,, M. Chatterjee, K.L.E., Y.O. Estrada, R.C. Genova, B. Girma, E.S. Kissel, A.N. Levy, S. MacCracken, P.R.M., and L.L.White (Eds.), Cambridge, United Kingdom and New York, USA, p. 1132.

J. Dronkers, J.T.E.G., L.W. Butler, J.J. Carey,, J. Campbell, E.J., C. McKenzie, R. Misdorp, N. Quin, K.L. Ries, P.C. Schroder, J.R., Spradley, J.G.T., L. Vallianos, and J. von Dadelszen, (1990) STRATEGIES FOR ADAPTION TO SEA LEVEL RISE, Report of the IPCC Coastal Zone Management Subgroup: Intergovernmental Panel on Climate Change. Intergovernmental Panel on Climate Change, Geneva. http://papers.risingsea.net/federal_reports/IPCC-1990-adaption-to-sea-level-rise.pdf

Jonkeren, O., Rietveld, P., van Ommeren, J., te Linde, A. (2013) Climate change and economic consequences for inland waterway transport in Europe. Regional Environmental Change, 1-13,DOI 10.1007/S10113-0130441-7, ISSN 1436-3798.

Jonkman, S.N., Hillen, M.M., Nicholls, R.J., Kanning, W., van Ledden, M. (2013) Costs of Adapting Coastal Defences to Sea-Level Rise- New Estimates and Their Implications. Journal of Coastal Research, 290, 12121226,DOI 10.2112/jcoastres-d-12-00230.1, ISSN 0749-0208 1551-5036.

Kates, R.W., Travis, W.R., Wilbanks, T.J. (2012) Transformational adaptation when incremental adaptations to climate change are insufficient. Proceedings of the National Academy of Sciences, 109, 7156-7161, ISSN 00278424.

Kosmatka, S.H., Kerkhoff, B., Panarese, W.C. (2011) Design and Control of Concrete Mixtures. Portland Cement Association, ISSN 0893122726.

Lonsdale, K.G., Downing, T.E., Nicholls, R.J., Parker, D., Vafeidis, A.T., Dawson, R., Hall, J. (2008) Plausible responses to the threat of rapid sea-level rise in the Thames Estuary. Climatic Change, 91, 145-169,DOI 10.1007/S10584-008-9483-0, ISSN 0165-0009.

Losada, M., Benedicto, M. (2005) Target Design Levels for Maritime Structures. Journal of Waterway, Port, Coastal, and Ocean Engineering, 131, 171.

Mimura, N., Yasuhara, K., Kawagoe, S., Yokoki, H., Kazama, S. (2011) Damage from the Great East Japan Earthquake and Tsunami-a quick report. Mitigation and Adaptation Strategies for Global Change, 16, 803-818, ISSN 1381-2386.

MSPA (Mississippi State Port Authority) (2007) Gulfport Master Plan Update 2007 - Final Report.

Muis, S., Verlaan, M., Winsemius, H.C., Aerts, J.C., Ward, P.J. (2016) A global reanalysis of storm surges and extreme sea levels. Nat Commun, 7, 11969,DOI 10.1038/ncomms11969, ISSN 2041-1723 (Electronic) 2041-1723 (Linking), Online at http://www.ncbi.nlm.nih.gov/pubmed/27346549.

Neumann, J., Hudgens, D., Herter, J., Martinich, J. (2011) The economics of adaptation along developed coastlines. Wiley Interdisciplinary Reviews: Climate Change, 2, 89-98, ISSN 1757-7799.

NGIA (National Geospatial-Intelligence Agency), (2014) World Port Index, 23rd Edition, Springfield, Virginia, USA. http://msi.nga.mil/MSISiteContent/StaticFiles/NAV_PUBS/WPI/Pub150bk.pdf

Nicholls, R.J., Brown, S.B., Hanson, S., Hinkel, J. (2010) Economics of Coastal Zone Adaptation to Climate Change. World Bank Discussion Papers, 10, International Bank for Reconstruction and Development / World Bank, , Online at http://eprints.soton.ac.uk/id/eprint/202135. 
Nordpil, 2009, World database of large urban areas, 1950-2050, Accessed July 15, 2014, Online at http://nordpil.com/go/resources/world-database-of-large-cities/.

NRC (National Research Council) (2010) America's Climate Choices: Adapting to the Impacts of Climate Change, Washington, DC.

PANYNJ (Port Authority of New York and New Jersey) (2012) Press Release (183-2012).

Parris, A., Bromirsji, P., Burkett, V., Cayan, D., Culver, M., Hall, J., Horton, R.,, Knuuti, K., Moss, R., Obeysekera, J., Sallenger, A.H., Weiss, J. (2012) Global Sealevel Rise Scenarios for the US National Climate Assessment. . NOAA Technical Report, National Oceanic and Atmospheric Administration, 37.

Peduzzi, P. (2014) Sand, rarer than one thinks. Environmental Development, 11, 208-218,DOI 10.1016/j.envdev.2014.04.001, ISSN 22114645.

PEER (Joint Legislative Committee on Performance Evaluation and Expenditure Review), (2006) The Impact of Hurricane Katrina on Mississippi's Commercial Public Ports and Opportunities for Expansion of the Ports. Mississippi Legislature, Jackson, MS. http://www.peer.state.ms.us/

Puertos del Estado (2002) Recommendations for Maritime Structures: General procedures and requirments in the design of harbor and maritime structures.

Pullen, T., Allsop, N.W.H., Bruce, T., Kortenhaus, A., Schüttrumpf, H., Meer, J.W.v.d., (2007a) EurOtop: Wave Overtopping of Sea Defences and Related Structures: Assessment Manual. http://www.overtoppingmanual.com/

Pullen, T., Kortenhaus, A., Allsop, N.W.H., Bruce, T., Schuttrumpf, H., (2007b) EurOtop - Wave Overtopping of Sea Defences and Related Structures: Assessment Manual. EA Environment Agency, UK. ENW Expertise Netwerk Waterkeren, NL. KFKI Kuratorium für Forschung im Küsteningenieurwesen, DE.

Rahmstorf, S. (2010) A new view on sea level rise. Nature Reports Climate Change, 44-45.

Reeve, D., (2010) On the Impacts of Climate Change for Port Design, 26th International Conference for Seaports \& Maritime Transport " Integration For a Better Future ".

Simpson, R.D., Toman, M.A., Ayres, R.U. (2005) Scarcity and growth revisited: natural resources and the environment in the new millennium. Resources for the Future.

TCRP (Transit Cooperative Research Program), (2010) Estimating Soft Costs for Major Public Transportation Fixed Guideway Projects. http://www.tcrponline.org/PDFDocuments/tcrp_rpt_138.pdf

Tebaldi, C., Strauss, B.H., Zervas, C.E. (2012) Modelling sea level rise impacts on storm surges along US coasts. Environmental Research Letters, 7, 014032, ISSN 1748-9326.

Thoresen, C.A. (2003) Port designer's handbook: recommendations and guidelines. Thomas Telford Services Ltd.

USACE (United States Army Corps of Engineering), (2012) Hurricane and Storm Damage Risk Reduction System Design Guidelines.

http://www.mvn.usace.army.mil/Portals/56/docs/engineering/HurrGuide/EntireDocument.pdf

USACE (United States Army Corps of Engineering), (2013) IHNC-Lake Borgne Surge Barrier. http://www.mvn.usace.army.mil/Portals/56/docs/PAO/FactSheets/IHNC-LakeBorgneSurgeBarrier.pdf 
USACE (United States Army Corps of Engineers), (2000) Planning Guidance Notebook. ER 1105-2-100. U.S. Army Corps of Engineers, Washington, DC 20314-1000.

http://planning.usace.army.mil/toolbox/library/ERs/entire.pdf

USACE (United States Army Corps of Engineers), (2008) Part V - Chapter 5 - Navigation Projects, Engineering and Design: Coastal Engineering Manual.

USCCSP (United States Climate Change Science Program), (2008) Impacts of Climate Change and Variability on Transportation Systems and Infrastructure: Gulf Coast Study, Phase I, in: Savonis, M., Burkett, V.R., Potter, J. (Eds.), A Report by the U.S. Climate Change Science Program and the Subcommittee on Global Change Research, Washington, DC. http://www.climatescience.gov/Library/sap/sap4-7/final-report/

USGS (United States Geological Survey), 2004, Shuttle Radar Topography Mission, 30 Arc Second scenes.

Vafeidis, A.T., Nicholls, R.J., McFadden, L., Tol, R.S.J., Hinkel, J., Spencer, T., Grashoff, P.S., Boot, G., Klein, R.J.T. (2008) A New Global Coastal Database for Impact and Vulnerability Analysis to Sea-Level Rise. Journal of Coastal Research, 244, 917-924,DOI 10.2112/06-0725.1, ISSN 0749-0208 1551-5036.

Vellinga, P., Katsman, C., Sterl, A., Beersma, J., Hazeleger, W., Church, J., Kopp, R., Kroon, D., Oppenheimer, M., Plag, H. (2008) Exploring high-end climate change scenarios for flood protection of the Netherlands. KNMI and Wageningen UR (Alterra, Earth System Science and Climate Change Group).

Vermeer, M., Rahmstorf, S. (2009) Global sea level linked to global temperature. Proceedings of the National Academy of Sciences, 106, 21-27.

Von Storch, H., Gönnert, G., Meine, M. (2008) Storm surges-An option for Hamburg, Germany, to mitigate expected future aggravation of risk. Environmental Science \& Policy, 11, 735-742, ISSN 1462-9011.

Washington Office of Financial Management (OEM), (2015) Guidelines for Determining Architect/Engineer Fees for Public Works Building Projects, in: Washington Office of Financial Management (OEM) (Ed.), Seattle, Washington. http://www.ofm.wa.gov/budget/instructions/capinst/aeguidelines.pdf

World Bank, (2010) The Costs to Developing Countries of Adapting to Climate Change: New Methods and Estimates, Global Report of the Economics of Adaptation to Climate Change Study. The World Bank Group, Washington, DC. 